\title{
Market review over the energy policies that stimulate, encourage and adopt building codes for nZEB promotion: the US and the European case
}

\author{
Ligia Moga ${ }^{1, *}$, Marcel Maghiar ${ }^{2}$ \\ ${ }^{1}$ Technical University of Cluj-Napoca, Civil Engineering and Management Department, 400027 Cluj-Napoca, Romania \\ ${ }^{2}$ Georgia Southern University, Civil Engineering and Construction, 30460-8077 Statesboro, GA, United States
}

\begin{abstract}
The building sector represents on a worldwide level, one of the larger energy consumers that should reduce its negative impact on the exterior environment. On a European level there are several directives that promote the transition to a decarbonized building sector that can be achieved by promoting the design and energy retrofit activity into nearly Zero Energy Building. The 2020 Climate and Energy Package, the 2030 Climate and Energy Framework and the 2050 Long-Term Strategy have the same goal, of cutting greenhouse gas emissions to admissible levels. In the United States the US Department of Energy alongside with the National Institute of Building Sciences set several targets for the development of a very energy efficient building stock. Thus, the paper offers an overview of the energy legislation implementation in European countries and in the United States, with a focus on identifying similarities and differences between the two regions. The first focus of the paper is on technical or legislative aspects identified in Europe and the United States in promoting nZEBs. Second, the definition of nZEB and its progress will be discussed and third several case studies will be discussed with the aim of identifying key points in achieving nZEB levels.
\end{abstract}

\section{Introduction}

Reducing energy consumptions in the building sector is still a major concern on a worldwide level, considering that is one of the sectors with very high consumptions but in the same time with solutions that can be tackled in order to reach the desired targets. Both in European countries and in the United States (US), the final energy consumptions in the building sector is around $40 \%$ from the total energy consumption, while in China the highest energy consumer being the industry sector, and the building sector coming second [1]. Based on statistics provided by the International Energy Agency (IEA), residential buildings are dominating the energy consumptions due to the presence of a large building stock [2]. Due to the facts that latest researches and statistics are indicating an increase of the primary energy consumptions and implicitly of the $\mathrm{CO}_{2}$ emissions [3], it is mandatory at a worldwide level that the concept of high performance energy efficient buildings to be clearly defined so that practitioners can design, build and retrofit based on design standards defined for this type of buildings. Thus, both in Europe and in the US, were developed several policies and plans for tackling the development of nearly Zero Energy Buildings (nZEB), in Europe or net Zero Energy Buildings (NZEB), in US. In other countries around the globe (i.e. Latin America, India and China) which are known to be high energy consumers, although the trend is known and several approaches were made, there still lacks a clear policy toward high performance energy efficient buildings compared to what Europe and US have done [1]. Several institutions like the Federation of European Heating, Ventilation and Air Conditioning Associations (REHVA), American Society for Heating and Refrigeration Engineers (ASHRAE), the European commission, the US Department of Energy (DOE) and other ministries are pushing the construction industry to follow the path of energy efficiency with a positive effect on the development of economy for all the involved stakeholders.

In the United States most contractors and builders are closely associating building codes with publications like the International Building Code. However, the International Energy Conservation Code (IECC) is a key part of determining a particular building capability of handling what the nature delivers from years of weather to historical major storms. The IECC sets in North America the minimum energy use and conservation requirements for existing and new buildings. This may include the opaque building envelope, lighting, HVAC equipment and ducts, doors and windows. Importantly, as the director of the Energy Efficient Codes Coalition in his blog series "Code Watcher" [4] says the IECC offers many life-saving benefits. These include retaining the heat or cold in a building (office, hospital, school or home) during extreme weather or power interruptions,

* Corresponding author: ligia.moga@ccm.utcluj.ro 
preventing moisture damage and mould, and keeping polluted air out and venting indoor pollutants to outside environment.

Adopting better building codes is more than a practice and a great idea, it can represent for owners a great investment. In accordance with the Natural Hazard Mitigation Saves: 2018 Interim Report [5], significant savings result from implementing mitigation strategies (such as building codes) in terms of safety, the prevention of property loss, and minimizing the disruption of day-to-day life. This report looks at the benefits of designing buildings to meet the 2018 International Residential Code and 2018 International Building Code-the model building codes developed by the International Code Council-versus the prior generation of codes represented by 1990 -era design and National Flood Insurance Program requirements. The report found a national benefit of $\$ 11$ for every $\$ 1$ invested [5]. Furthermore, this report found that adopting current codes and building to these levels of requirements have added more than 30,000 new jobs to the construction-materials industry and generated a three percent annual increase in utilization of domestically produced materials in new construction (over what would have been used if buildings were designed as they were in 1990).

Building energy codes are accountable for overwhelming savings. DOE estimates that energy codes will save domestic homeowners and business $\$ 126$ billion in energy costs through 2040 [5], while in Europe it was concluded that energy efficiency measures will generate for European businesses and consumers net direct savings of about 107 billion euro by 2020, while an additional euro 100 billion annual cost savings can be expected [6].

However, the benefits of energy codes like the IECC go beyond energy savings. As it is further highlighted, the IECC promotes structural and safety protection by:

- Reducing deaths and the related health issues from exposure to extreme temperatures - the Centers for Disease Control and Prevention estimates that about 2,000 Americans die each year due to extreme weather conditions. In this sense, more efficient buildings retain better comfortable temperatures from air conditioning and heating during cold breaks and heat waves

- Improving indoor air quality - a great insulated and purposefully ventilated building will keep pollutants outdoors and ensures healthy air flow inside the living areas

- Enhancing fire codes - IECC's tight building envelopes slow the spread of fires by sealing cracks, holes, and other draft openings and by separating conditioned from unconditioned spaces

- Providing greater moisture management - it prevents construction material rot, harmful mould and its growth; a strong building envelope reduces the phenomena of condensation and ice stemming

- Enhancing resiliency - more efficient buildings allow individuals to shelter in place longer during power failures and outages

Buildings constructed to meet or exceed these modern building and energy codes may consequently induce an important role in reducing the overall economic impact in cases of natural disasters. However, as witnessed all over United States, the key to ensuring that building and energy codes function properly is implementation and administration. A building code is only effective if there is enforcement and sufficient inspections to verify that construction is completed according to that code requirements. State, City and Local governments need to make the necessary investment in code officials training and inspection services to ensure this ultimate goal is apprehended.

\section{Definitions and policies of high performance energy efficient buildings}

High performing energy efficient buildings are going to dominate the construction market in the near future due to the way stricter policies and design standards are shaping the way that buildings will be designed and build. The market is expecting designers and builders to deliver very low energy efficient buildings, which are durable and produced at optimum costs. Thus, the construction industry needs to understand what defines a high performant energy efficient building in order to really contribute to a more sustainable and energy efficient environment.

\subsection{European case}

The European climate strategies and targets defined several deadlines up to 2050 , in order to achieve the transformation towards a low-carbon economy by 2050 [7]. The strategies focus on reaching decreased energy consumptions levels (i.e. improved energy efficiency), reduced greenhouse gas emission (GHG) and increase renewables in the energy mix (see table 1).

Table 1. Climate strategies and targets. [7].

\begin{tabular}{|c|c|c|c|}
\hline & GHG & $\begin{array}{c}\text { Energy } \\
\text { Efficiency }\end{array}$ & renewables \\
\hline $\begin{array}{c}2020 \text { climate } \\
\text { and energy } \\
\text { package }\end{array}$ & $20 \%$ & $20 \%$ & $20 \%$ \\
\hline $\begin{array}{c}2030 \text { climate } \\
\text { and energy } \\
\text { framework }\end{array}$ & $40 \%$ & $32.5 \%$ & $32 \%$ \\
\hline $\begin{array}{c}2050 \text { long- } \\
\text { term strategy }\end{array}$ & \multicolumn{3}{|c|}{$90 \%$ - Going climate neutral } \\
\hline
\end{tabular}

In the construction sector, the implementation of this policies are given by the European directive for the Energy performance of Buildings (EPBD), which has undergone various changes over the years, as it follows [8]:

- Directive 2002/91/EC: it established mandatory requirements for the EU member states for buildings by defining the Energy Performance Certificate (EPC), needed at renting, buying or selling a building or a unit of a building.

- Directive 2010/31/EU defined the nearly Zero Energy Building (nZEB) in Annex I and sets clear targets for 
public buildings by 31 December 2018 and for all new buildings by 31 December 2020 .

- Directive 2012/27/EU requires member states to retrofit a minimum of $3 \% / y e a r$ of existing buildings owned and occupied by central governments.

- Directive 2018/844/EU sets the trend for energy retrofit of existing building stock to nZEB levels.

The annex I of the Directive 2010/31/EU defines the nZEB as being: “...nearly zero-energy building' means a building that has a very high energy performance, as determined in accordance with Annex I. The nearly or very low amount of energy required should be covered to a very significant extent by energy from renewable sources, including energy from renewable sources produced on-site or nearby;" As mentioned by other authors [8], the definition does not give any technical information and implies that each member state will have to define by using several indicators what a nearly zero level means. This indicators are: primary energy consumption in $\mathrm{kWh} / \mathrm{m}^{2} \mathrm{yr}$, final energy consumption in $\mathrm{kWh} / \mathrm{m}^{2} \mathrm{yr}$, thermal performance of the building envelope (thermal resistance/transmittance) and percentage of renewable energy in the energy mix. A definition for nZEB energy balance mentioned by Kurnitski [9] is (1):

$$
\begin{gathered}
E_{P}=\sum_{i}\left(E_{d e l, i} \cdot f_{d e l, i}\right)-\sum_{i}\left(E_{\exp , i} \cdot f_{\exp , i}\right) \\
E P=\frac{E_{P}}{A_{\text {net }}}
\end{gathered}
$$

where $E_{P}$ is the primary energy $[\mathrm{kWh} / \mathrm{yr}] \mathrm{E}_{\mathrm{del}, \mathrm{i}}$ is the delivered energy for energy carrier $i ; E_{\text {exp, } i}$ is the exported energy for energy carrier $\mathrm{i}$; $\mathrm{f}_{\mathrm{del}, \mathrm{i}}$ is the primary energy factor for the delivered energy carrier $\mathrm{i}$; $\mathrm{f}_{\mathrm{exp}, \mathrm{i}}$ is the primary energy factor for the exported energy carrier i., $E P_{P}$ is the primary energy indicator $\left[\mathrm{kWh} / \mathrm{m}^{2} \mathrm{yr}\right]$ and $A_{n e t}$ is the useful floor area $\left[\mathrm{m}^{2}\right]$ calculated according to national definitions. It is worth mentioning that the energy balance refers to non-renewables sources and the $f_{\text {del, } i}$ may or may not be equal to $f_{\text {exp, } i \text {. }}$

Another term subjected to a different definition for each member state is "nearby" and "cost optimum levels". The Delegated Regulation No 244/2012 [10], defined the cost-optimal level as being "the energy performance level which leads to the lowest cost during the estimated economic lifecycle". Each member state had to define the reference building and then apply the energy efficient measures with the scope of reducing the primary energy consumption and identifying the most advantageous economical solution. The cost-optimum concept it also defines a minimum level that must be met in order to reach an nZEB level.

Although several definitions were proposed along the years, some European countries define the nZEB based on the primary site energy approach, while other countries (e.g. Norway, Spain Great Britain) use carbon emissions as the main indicator. In other countries (e.g. Romania, Austria) the carbon emissions are considered an additional indicator, while the main being the primary energy consumption [11]. Thus, each member state of
EU had to identify and define the maximum admitted primary energy consumption level based on building type, as shown in table 2.

Table 2. Primary energy nZEB levels in some EU Member

\begin{tabular}{|c|c|c|}
\hline Country & $\begin{array}{c}\text { Residential } \\
\text { Buildings } \\
{\left[\mathrm{kWh} / \mathrm{m}^{2} \cdot \mathrm{yr}\right.} \\
\text { or Energy class }]\end{array}$ & $\begin{array}{c}\text { Non-residential } \\
\text { Buildings } \\
{\left[\mathrm{kWh} / \mathrm{m}^{2} \cdot \mathrm{yr}\right.} \\
\text { or Energy class }]\end{array}$ \\
\hline Austria & 160 & 170 \\
\hline Belgium & $45 / 30 / 60 *$ & $(90-2.5) *(\mathrm{~V} / \mathrm{S}) / 40 / 60$ \\
\hline Bulgaria & $\sim 30-50$ & $\sim 30-50$ \\
\hline $\begin{array}{c}\text { Czech } \\
\text { Republic }\end{array}$ & $75-80 \% \mathrm{PE}$ & $90 \% \mathrm{PE}$ \\
\hline Denmark & 20 & 25 \\
\hline France & $40-65$ & $70 / 110 * *$ \\
\hline Germany & $40 \% \mathrm{PE}$ & $\mathrm{n} / \mathrm{a}$ \\
\hline Ireland & $45 * * *$ & $60 \% \mathrm{PE}$ \\
\hline Italy & Class A1 & Class A1 \\
\hline Lithuania & Class A++ & Class A++ \\
\hline Luxemburg & Class AAA & Class AAA \\
\hline Netherland & 0 & 0 \\
\hline Poland & $60-75$ & $45-70-190$ \\
\hline Romania & $93-127$ & $50-192$ \\
\hline Spain & Class A & Class A \\
\hline Sweden & $30-75$ & $30-105$ \\
\hline UK & $\sim 44$ & $\mathrm{n} / \mathrm{a}$ \\
\hline
\end{tabular}
States. New buildings. Adapted from [12].

In Romania, the nZEB levels for primary energy and $\mathrm{CO}_{2}$ emissions were defined by [13] based on the type of building (i.e. individual residential buildings, collective residential buildings, office buildings, educational buildings and hospitals), climatic zone $\left(1^{\text {st }}-12^{\circ} \mathrm{C}, 2^{\text {nd }}-\right.$ $\left.15^{\circ} \mathrm{C}, 3^{\text {rd }}-18^{\circ} \mathrm{C}, 4^{\text {th }}-21^{\circ} \mathrm{C}, 5^{\text {th }}-24^{\circ} \mathrm{C}\right)$, and two targeted dates (i.e. 31.12.2018 and 31.12.2020). For the second deadline, the values from table 3 should be reached by 31.12.2020.

Table 3. Primary energy and $\mathrm{CO}_{2}$ emissions for $\mathrm{nZEB}$ in Romania [13].

\begin{tabular}{|c|c|c|}
\hline Country & $\begin{array}{c}\mathrm{PE} \\
{\left[\mathrm{kWh} / \mathrm{m}^{2} \cdot \mathrm{yr}\right]}\end{array}$ & $\begin{array}{c}\mathrm{CO}_{2} \text { emissions } \\
{\left[\mathrm{kgCO}_{2} / \mathrm{m}^{2} \cdot \mathrm{yr}\right]}\end{array}$ \\
\hline $\begin{array}{c}\text { individual } \\
\text { residential } \\
\text { buildings }\end{array}$ & $98 / 111 / 145 / 189 / 217$ & $24 / 30 / 40 / 42 / 54$ \\
\hline $\begin{array}{c}\text { collective } \\
\text { residential } \\
\text { buildings }\end{array}$ & $93 / 100 / 111 / 127 / 135$ & $25 / 27 / 3035 / 37$ \\
\hline office buildings & $45 / 57 / 69 / 83 / 89$ & $12 / 15 / 19 / 24 / 24$ \\
\hline $\begin{array}{c}\text { educational } \\
\text { buildings }\end{array}$ & $92 / 115 / 136 / 170 / 185$ & $24 / 30 / 37 / 49 / 53$ \\
\hline hospitals & $76 / 97 / 115 / 142 / 167$ & $21 / 26 / 32 / 41 / 48$ \\
\hline
\end{tabular}

*climatic zones: $1^{\text {st }} / 2^{\text {nd }} / 3^{\text {rd }} / 4^{\text {th }} / 5^{\text {th }}$

On the European market, but not only there, exist several approaches that can be regarded as nZEB. Passive House (PH) is a German approach developed by 
the Passivhaus Institut in the '90s. The passive house is defined by five basic principles that must be met to achieve the passive house certification. The energy consumption indicators are defined by reaching a maximum of $120 \mathrm{kWh} / \mathrm{m}^{2} \mathrm{yr}$ of primary energy and a maximum of $15 \mathrm{kWh} / \mathrm{m}^{2} \mathrm{yr}$ of heating or cooling demand. PassivHaus is also a popular option for its simplicity and has its presence in the United States, Canada, Japan and Korea.

Another concept is the Active House which was developed by Velux in Denmark. The building standard is similar to the PH standard, but it also focuses on the occupant's well-being. The definition encompasses a holistic view Comfort, Energy and Environment [14]. Another concept is the 2000 Watt Society that is a Swiss concept which is defined by a policy of reducing global energy consumptions by three and GHG emissions by eight by 2100 . The concept was developed by the Swiss Society of Engineers and Architects along with the Swiss Federal Energy Office [15].

The environmental certification of buildings, also known as "green certification", started in Europe with the BREEAM methodology in the United Kingdom, still being one of the standard with the most certified buildings on a worldwide level. On a European level are also used DGNB from Germany, HQE from France, MINERGIE from Switzerland and other locally adopted methodologies. In Romania the research project SIR developed an environmental certification methodology [16], which is still not placed on the market as mandatory. Moving more towards the east-Asian regions, we see that the Green Mark scheme, a rating system established by the Building Construction Authority of Singapore is growing in popularity and it is now widely used. All environmental certification methodology give around $25 \%$ to $35 \%$ when assessing the energy efficiency criteria, but the rest is given to other important criteria that are certifying a building.

\subsection{US case}

The National Institute of Building Sciences (NIBS) and New Buildings Institute (NBI) have developed a new tool, with support from the U.S. Department of Energy and the Northwest Energy Efficiency Alliance, to help authorities challenge energy use in buildings. The LifeCycle Energy Performance Framework for Cities is now available on the Whole Building Design Guide (WBDG) web portal. Buildings are responsible for a significant portion (most of the time the largest portion) of energy use or greenhouse-gas (GHG) emissions within city borders. Thus far, the cities setting quantifiable objectives to reduce energy use or GHG emissions are finding policies focused only on new construction are not enough to achieve such goals. They need a coordinated tactic that would also address the existing building stock.

NIBS and NBI convened a team of energy thought leaders to identify strategies in cities which could implement and address the energy use of buildings in an all-inclusive manner. Cities require wide-ranging, long- term strategies that include policies, programs, organizational resources, tools and ongoing funding sources. Unfortunately, just a few jurisdictions have some of these pieces in place. However, up until recently, there was no single resource that has described how these pieces relate to each other or how to implement them as a comprehensible entity. The LifeCycle Energy Performance Framework for Cities does this nowadays [17]. This web-based resource offers introduction and guidance tabs and through a series of levels and drop downs, users can customize their own path to implement life-cycle-based energy policies and print out tracking reports based on their responses. The top level - the organizational basis of the Framework consists of four overarching categories: Leadership; Data, Analysis, and Applications; Mechanisms; and Ensuring Results. The categories are each broken into components with a brief description of the policy action, and examples and links for more information. Each component has individual activities, structured as Policies, Actions, Resources and Tools, which the user can select based on the priorities and potential strategies of interest to the respective jurisdiction or administration:

- Policies - require legislative or regulatory action by city leadership (mayor, city council, city administration, etc.), or within administrative agencies

- Actions - are steps that generally should be undertaken at an administrative level

- Resources - are either investments or competences that support comprehension of program goals.

- Tools - can be developed internally at the city level or at a national level and provide the mechanism to achieve a specific strategy.

The user can use the drop-down menus associated with each individual element to designate the status of the element, including, In Place (currently implemented and functioning), In Process (in the process of being implemented), In Planning (resources and processes are being identified for implementation in the near term), or In Projections (to be implemented at some point in the future) [17]. NBI has created a companion toolkit that can help users of the Framework to lead by example by getting on a path to zero-energy and zero-carbon in their own buildings while enhancing policies affecting municipal buildings and the community at large [18]. There are increasing number of cities, counties, and states in the United States committed to reducing their greenhouse-gas emissions. An organized list provided with leading energy goals, policies, and energy stretch codes from states and local jurisdictions, as well as programs that support jurisdictions can be found at [19]. Their resources include energy and climate action plans, strategic plans, and stretch codes.

The Advanced Jurisdictions Policy Map [19] identifies where policies are being implemented, as well as where further information is available (on this page or within NBI's off-line zero-energy policy Database). For a full list of up-to-date policies, interested readers can go to ACEEE (American Council for an Energy-Efficient Economy) State and Local Policy Database [20]. This resourceful web database contains ranking for cities and 
states based on energy-efficiency scorecards and keyenergy indicators.

State and local governments can lead by example by promoting energy-efficiency programs and policies for public facilities, equipment, and government operations through energy data management and evaluations, energy-efficiency building standards, ratifying existing building retrofit programs, acquiring energy-efficient appliances and equipment (including vehicles), and establishing energy-efficient operations and maintenance procedures. The site from DOE provides sample programs and standards for public entities [21]. Working with the NIBS and a broad group of market stakeholders, DOE developed a common national zero-energy building definition with supporting nomenclature and guidelines to facilitate its use. Federal government agencies, as well as state and local governments have begun to move toward targets for zero-energy buildings, but definitions of what it means to have a zero-energy building have varied from region to region and from one building professional to another. A broadly accepted definition of zero-energy building metrics and boundaries is foundational to efforts by governments, utilities, or private entities to recognize or incentivize zero-energy or near zero-energy buildings. [22]. Therefore, thousands of project teams throughout the country seek to push the envelope and develop zero or near zero-energy buildings. A zero-energy building produces "enough renewable energy to meet its own annual energy consumption requirements, thereby reducing the use of non-renewable energy" for buildings. This definition also applies to campuses, portfolios, and communities. In addition to providing clarity across the industry, this DOE definition publication provides guidelines for measurement and implementation, specifically explaining how to utilize the definition for building projects. [21]. A definition for the energy balance of NZEB as defined by DOE is given at (3) [12]:

$E_{\text {source }}=\sum_{i}\left(E_{d e l, i} \cdot \gamma_{d e l_{i} i}\right)-\sum_{i}\left(E_{g x p_{i} i} \cdot r_{e x p, i}\right) \leq 0$

where $E_{\text {del, } i}$ is the delivered energy for energy type $i$, $E_{\text {exp,i }}$ is the exported on-site renewable energy for energy type $\mathrm{i} ; \mathrm{r}_{\mathrm{del}, \mathrm{i}}$ is the source energy conversion factor for the delivered energy type $\mathrm{i} ; \mathrm{r}_{\text {exp,i }}$ is the source energy conversion factor for the exported energy type $i$.

Similar to European policies, DOE has also set targets for 2020 to achieve "marketable zero energy homes" and by 2025 "commercial zero energy buildings". California set the target for 2030 when all new commercial buildings and $50 \%$ of the existing commercial buildings will be NZEB [11].

The energy rating systems in the US vary from a multitude of considerations between many popular green rating systems, which are also used in other parts of the world for rating and assessing construction projects and the built environment. While the general direction of these rating systems and their parameters are seemingly similar, their focus areas differ on their own independent green rating scoring systems through point allocations and point weightage. An important role it plays the energy conservation and energy efficiency programs and distribution of points for construction of buildings with the intent to achieve an nZEB status as close as possible. The well-known Leadership in Energy and Environmental Design (LEED) is leading the US market, coming second on a worldwide level after BREEAM. Other certification programs like Energy Star, Living Building Challenge, WELL are also used along with existing NZEB targets. In order for NZEB targets to be met, it is necessary to shape the assessment of the energy criteria to meet the required NZEB targets.

\subsection{Other approaches for NZEB definition}

Considering the debate over the terms of nZEB, NZEB or ZEB, it is worth mentioning the additional definitions proposed by Torcellini et al [23] in 2006 and later in 2011, as Net Zero Site Energy (NZSiEB), Net Zero Source Energy (NZSoEB), Net Zero Energy Costs (NZEC), and Net Zero Emissions Building (NZEB). Although that maybe part of the definitions encountered several modifications, they still represent a starting point in addressing NZEBs. REHVA has also addressed the technical definition of nZEBs, trying to identify the different perspectives of applying the definition around the world [12]. ASHRAE considered that NZSiEB satisfies the path toward high performing buildings, but they simplified the used term to NZEB, which refers to a building that has a net zero energy balance when accounted at the site, described by a two-way energy exchange with the grid. The definition that states that a NZEB is a building connected to the grid was also embraced by the International Energy Agency (IEA), Solar Heating and Cooling (SHC) Task 40, and the Energy Conservation in Buildings and Community systems (ECBCS) Annex 52. They also defined the nearly Net Zero Energy Building (NZEB) and Net Plus Energy Building (NPEB), which is considered to be a building that produces more energy from alternative sources (i.e. renewables) that it imports over a year. Other definitions found in Europe are Zero Carbon Buildings (ZCB) in the United Kingdom, Positive Energy Buildings (PEB) in France and Denmark and Climate Neutral Buildings (CNB) in Germany. As mentioned by D'Agostino [12], ZEB can also be defined based on the energy production source, as Wind-ZEB, Wind- Solar thermal heat pump ZEB, PV-ZEB, PVSolar thermal heat pump ZEB.

\section{Particularities in implementing nZEB}

The way that the nZEB or NZEB definition are applied around the world, leads to several differences and sometimes barriers in applying this requirements. In Europe the implementation of the EPC has also shifted the way towards nZEBs, but not always the energy rating scale expressing the total energy consumption of a building, is in line with the nZEB levels. In the Romanian case the energy rating scale are being updated this year and a new energy class A+ will be included, thus trying to align with the nZEB levels defined in 
2016. Nevertheless, the A+ class minimum level to be achieved still does not met the nZEB levels, although the values are close to those. Another difference in reaching nZEB talks about the technical solution employed, low tech or high tech as mentioned by [24]. Low-tech can sometime drive to lower performances compare to hightech solutions. In the same time high-tech implies more use of technologies which translates to higher energy intensities and continuous maintenance.

As it was mentioned by [12], PE talks less about the performance of the building and more about the efficiency of a system and energy generation mix. That is why it can happen when doing the calculation for a building to be defined as being nZEB but not NZEB. In the same time it is difficult to have a harmonized PE value among EU member states, considering that each has defined their characteristic PE conversion factors value and along the years it is subjected to changes. For district heating values can range from 1.0 Austria to 1.20 France, Germany, Italy, Romania, Spain and 0.7 Finland. For gas is 1.0 Finland, France, Germany, Italy, Romania, Spain and 1.13 Spain. For Electricity is 1.89 Spain, 1.91 Austria, 2.18 Italy, 2.45 Germany, 2.53 Romania, 2.69 Finland and 2.72 France, while in the US there are continuous updates for the hourly energy emission factors [11].

Other differences in applying nZEB levels is the calculation methodology of the energy performance of buildings, considering its variations around de European member states. The Romanian methodology evaluates the heating, cooling, ventilation, domestic hot water and lighting energy consumptions, but no household appliances as Austria does. Also, in the case of nonresidential buildings several countries consider also the energy consumptions from elevators and escalators although that these are not included in the official requirements or standards. Thus, it is difficult to have a homogenous methodology across member states, and also difficult to certify if an nZEB in a country is also an nZEB in a different country. Another issues talks about the boundary to be considered when referring to renewable energy sources (i.e. on-site, nearby or far), which in some particular situations is very difficult to define. Even the percentage of the renewable energy in the energy mix varies across Europe, some of them including a mandatory minimum share of renewables, as it is the case of Romania (i.e. minimum of $10 \%$ rising to minimum of $30 \%$ starting from 2020). Although that some countries like United Kingdom, Spain and Norway have considered also the environmental implications for the energy carrier by focusing on the $\mathrm{CO}_{2}$ emission or GHG emission, other countries are still focused on the indicator defined by the annual primary energy use.

Another aspect is that of the embodied energy of the building which is still not considered in nZEB definition. The trend is that of going carbon neutral, so that the nZEB must be redefined to include the aspect of Life Cycle Assessment, which could redefine the ZEB by considering when calculating the primary energy, both operational and embodied energy. Based on nowadays definition, the electric grid should also be rethought so that is able to uptake the exported energy and also provide storing capacities. Thus, urban planning should rethink how the city will interact with the nZEB districts. Also an interconnection between nZEB and smart buildings must be redefined, so that the two will have similar aims.

The particularities in implementing nZEB policies and therefore the transfer of energy-efficient building codes to implementation phases, are also related to the uncertainty of end-users' operating practices and their handling of the technological equipment within buildings as unknown energy consumption parameters. As an example, in the construction of residential units for sale purposes, it may not be readily available to know for the new owners how important it is to dwell into an nZEB home. Future owners should always think about minimizing the waste of energy in the long-run; in the same time, they should be aware of minimizing the maintenance and its associated costs required to keep the nZEB status gained. This is an important consideration for the "operation" phase of the units along with the critical aspect of life-cycle cost of ownership which need to be economized to a lower level than one of the median regional/community energies-consumption levels. nZEB is achievable and effective in all cold, hot or humid climates both in the EU and United States and priorities may be similar, however they differ in envelope considerations for temperature/humidity specific to each region. Also, training to maintain economized building operations is essential in these climates and this may create a valuable habitual owner component for a longterm savings-generation plan.

\section{4 nZEB Case studies}

\subsection{Romanian case}

The implementation of the EPBD is under the responsibility of the Ministry of Public Works, Development and Administration (former MDRAP). In 2014 the "Plan for increasing the number of nearly zero energy buildings - Romania" was released, document that included cost-optimum solutions and the nZEB values for five types of buildings characterizing the Romanian building stock. Two years later, the 372 Law was updated [25] and the Ordinance no.13 was approved. Further on, the Order 386 [13] was implemented and the nZEB values came into force starting with the first EU deadline. The 386 Order, also came with the final variant of the climatic map for the winter period, thus the exterior temperature for the $5^{\text {th }}$ climatic zone was redefined (i.e. $5^{\text {th }}-24^{\circ} \mathrm{C}$ ). In order to move the designers markets toward the first nZEB deadline of 2019, in 2017 a new Ministerial Order 2641[26] came into force. Thus, the methodology Mc001-2006 was amended with reinforced requirements for different building categories (i.e. residential and nonresidential buildings), for the thermal resistances of building components, requirements for the global heat transfer coefficient denoted by $\mathrm{G}$, and requirements for the maximum annual primary energy demand for space heating (i.e. non-renewables). In the same document, 
$\mathrm{CO}_{2}$ emissions factors were updated. Although that at the moment there is no available data regarding newly constructed or existing nZEB buildings, defined accordingly to national legislation, all local communities that have more than 5000 inhabitants must initiate multiannual plans to develop the nZEB building stock, for both new and existing buildings.

In 2020 the updated version of the energy performance methodology will be introduced, with higher values for thermal resistances of the building components and lower values for the global heat transfer coefficient, which translates into stricter regulation. In the same time the renewable energy share will increase to a minimum of $30 \%$ in the energy mix. The EPC will be defined by new values for each type of energy consumer, and values will be differentiated on various building categories. Although that there is no evidence of nZEBs, it is worth mentioning that starting from 2008, 19 buildings have been certified as passive houses, 17 new residential buildings, 1 new office building and one retrofitted residential building (see https://passivehousedatabase.org/). In the same time, education regarding nZEB design is present in higher education curricula both at bachelor and master level [27]. Considering the already established path by passive house designers, the nZEB designers will just follow this or a similar path towards new approaches. In the same time, in several cities the town administration offers tax reductions for green certified buildings that are also A energy class.

\subsection{US case}

A list of DOE Zero-Energy ready home resources can be found at [28], however a similar resources page for commercial buildings gathered by DOE can be found at [22]. nZEBs are all using cost effective measures to reduce energy usage therefore lower consumption through energy efficiency, including renewable energy systems that produces enough energy to meet the building energy demands. In this paper, the authors chose three representative case studies (educational, office and residential buildings) from the United States with the intent of revealing the cost-effective measures which make the respective buildings adhere to the nZEB status through implemented energy policies and efficient building codes.

Case study 1: Berkeley, CA, USA, West Branch of the Berkeley Public Library [29]. A building with $1113 \mathrm{~m}^{2}$. First green activity in 2012. This building has a 5-year timeline with 5 green activities including a LEED Platinum certification: AIA/COTE Top Ten Green Projects; awarded LEED platinum on 03/29/2016 (space use: public assembly). NBI Zero Energy Buildings 2015: Total building actual EUI: 22; Site renewable EUI: 23; Net building EUI: -2. Net Zero Energy Building Certification awarded on 03/30/2014

Case study 2: Phoenix, AZ, USA. DPR Construction's Phoenix Regional Office [30]. An Office building with $1536 \mathrm{~m}^{2}$. First green activity in 2011. This building is green and energy efficient because it has 8 green activities that achieved outcomes of energy efficient design, water use reduction, sustainable site selection and development, responsible materials selection and waste management, enhanced indoor environmental quality, and energy efficient operations. Verified NBI Zero-Energy Buildings 2015 (Total building actual EUI: 27, Site renewable EUI: 30, Net building EUI: -3 . Whole Building Design Guide Case Study reported in 06/20/2014. NBI Getting to Zero 2014 case study. SBIC Beyond Green High-Performance Building Awards in 2014. Livable Buildings Awards honorable mention in 2014. Net Zero Energy Building Certification awarded on 05/08/2013. LEED NC 2009, Platinum level awarded on 07/11/2012, Space use: office; LEED NC 2009 registered on 04/19/2011. Case study 3: Austin, TX, USA Willowbrook House [31]. First green activity in 2014; Net Zero Energy Building Certified on 05/21/2014. Considering the mentioned cases, compared to European approach, the nZEB fund from US is focused on two aspects, i.e. energy efficiency and sustainability.

\section{Conclusions}

Entering a new decade, nZEB must be a priority in energy consumption policies and adoption of energyefficient building codes in both Europe and US; as such, nZEB mandated by U.S. federal buildings by the year 2030 will assist in promoting more net-zero (or nearzero) energy policies and building codes. In Europe, the nZEB definition could suffer several adjustments along with the development of new technical solutions and decrease of prices in accessing them. In the same time, it exists a possibility for nZEB to develop in the near future, closer to an updated version of what NPEB is defined today. At the moment, nZEB is fulfilled to some extent, more on paper and less in practice in some countries, due to its unapproachable consumption levels. More training programs tailored for designers should be funded due to lack of knowledge in addressing energy efficiency in design. The community must be trained in how the basic features of an nZEB can be understood and achieved, and levels maintained in operation. Although that the PH standard has won a large part of the building sector, and some designers identify it as being the only proper approach for nZEB, the construction market is still searching for more affordable solutions to be developed. Thus, research funding for nZEB technical solutions and buildings incentives for both public and private sector, must be tailored to increase the number of nZEBs. Harmonization on a global level for the nZEB or ZEB definition, is a very hard task. Nevertheless, with an increase in the number of nZEB in the next 20-30 years, the "nZEB status" will become more of a common standard and gain a definite place on the building markets.

\section{Acknowledgments}

The research was financed by "Susținerea excelenței în cercetarea din domeniul nanotehnologiilor și materialelor avansate" - ExNanoMat Contract nr. 21 PFE-2018. 


\section{References}

1. L. Belussi, et. al, J. of Build.Eng. 25, (2019)

2. IEA, Transition to Sustainable Buildings, retrieved from constructionclimatechallenge.com/2015/03/09/transi tion-to-sustainable-buildings-strategies-a-newguide/ (2013)

3. D. Ürge-Vorsatz, L.F. Cabeza, S. Serrano, C. Barreneche, K. Petrichenko, Renew. Sustain. Energy Rev. 41, 85 (2015)

4. B. Fay. The IECC Is a Life Safety Code: Make It the Law. Retrieved from:

https://codewatcher.us/codes/the-iecc-is-a-lifesafety-code-make-it-the-law/, (2019)

5. Natural Hazard Mitigation Saves Study. Retrieved from: https://www.nibs.org/page/mitigationsaves, (2019)

6. Institute for European Environmental Policy (IEEP), Review of costs and benefits of energy savings, (2013)

7. Climate strategies \& targets. Retrieved from: https://ec.europa.eu/clima/policies/strategies_en

8. F.Asdrubali, I. Ballarini, V. Corrado, L. Evangelisti, G. Grazieschi, C. Guattari, J. Build. and Envir. 147, 461 (2018)

9. J. Kurnitski, Technical definition for nearly zero energy buildings, J. REHVA, (2013)

10. Commission Delegated Regulation No244/2012 Supplementing Directive 2010/31/EU of the European Parliament and of the Council on the energy performance of buildings by establishing a comparative methodology framework for calculating cost-optimal levels of minimum energy performance requirements for buildings and building elements, Official J. of the EU, (2012)

11. F. Asdrubali, U. Desideri, Handbook of Energy Efficiency in Buildings, 175 (2018)

12. D. D'Agostino, L. Mazzarella, J. of Build. Eng. 21 , 200 (2019)

13. Order 386 for the modification and completion of the technical regulation "Norm regarding the thermotechnical calculation of the construction elements of the building envelope", indicative C107-2005, approved by the Order of the Minister of Transport, Construction and Tourism no. 2055/2005, (2016)

14. K. E. Eriksen, J. REHVA, 6 (2013)

15. 2000 Watt Areal, Energy Future Switzerland. Energy Efficiency/Renewable Energies, (2014)

16. L.M. Moga, A. Puskas, WIT Tran. on Ecol. and the Env. 176, 185 (2013)

17. Life-Cycle Energy Performance Framework for Cities. Version 1.0. Retrieved from: https://www.wbdg.org/additionalresources/tools/life-cyle-energy-performanceframework-cities, (2019)

18. Getting to Zero Forum. State and Local Government Toolkit. Retrieved from: https:/gettingtozeroforum.org/local-governments/, (2019)

19. Getting to Zero Forum. Zero Energy Policies

Resources. Retrieved from:

https://gettingtozeroforum.org/policy-resources/, (2020)

20. American Council for an Energy-Efficient Economy, State and Local Policy Database. Retrieved from: https://database.aceee.org/, (2020)

21. Energy Efficiency Policies and Programs. DOE webpage. Retrieved from:

https://www.energy.gov/eere/slsc/energy-efficiencypolicies-and-programs, (2019)

22. Zero Energy Buildings. DOE webpage. Retrieved from: https://www.energy.gov/eere/buildings/zeroenergy-buildings, (2019)

23. P. Torcellini, S. Pless, Zero and net-zero energy buildings + homes, (2011)

24. S. Attia, Net Zero Energy Buildings (NZEB), 21 (2018)

25. 156 Law, regarding the approval of the Government Ordinance no.13/2016 for the modification and completion of the Law 372/2005 of energy performance of buildings, (2016)

26. Order 2641 regarding the modification and completion of the technical regulation "Methodology for calculating the energy performance of buildings", approved by the Order of the Minister of Transport, Construction and Tourism no. 157/2007, (2017)

27. Green Buildings Master, Faculty of Civil Engineering, Technical University of Cluj-Napoca, https://constructii.utcluj.ro/admitere-master.html

28. DOE Zero Energy Ready Home Resources. DOE webpage. Retrieved from:

https://www.energy.gov/eere/buildings/doe-zeroenergy-ready-home-resources, (2019)

29. Berkeley Public Library. West Branch, Berkeley, CA 94702. Retrieved from:

https://www.berkeleypubliclibrary.org/locations/wes t-branch, (2014)

30. DPR Construction Net-Zero Energy Phoenix Regional Office. DPR Construction, Phoenix, AZ. Retrieved from: https://www.dpr.com/projects/dprconstruction-phoenix-regional-office, (2020)

31. International Living Future Institute. Net Zero Energy Certified Willowbrook House, Austin, TX. Retrieved from: https://living-future.org/lbc/casestudies/willowbrook-house/, (2020) 